\title{
Trade Relations Between China and The Czech Republic: An Analysis of Complementarity and Competition
}

\author{
Shuqi Yao
}

\author{
Shanghai University \\ Corresponding author. Email: susieyao2021@163.com
}

\begin{abstract}
Trade relations between China and the Czech Republic have intensified in recent years and still have great potential for growth. This paper aims to analyse the current trade status and study the complementarity and competition between China and the Czech Republic. The empirical analysis is based on models of international trade, including trade complementarity index (TC), trade competition index (TCI) and export similarity index (ESI). Results indicate that China's exports have strong complementarities with Czech Republic's imports in labour-intensive and capital-intensive commodities, while complementarities of Czech Republic's exports to China's imports are resource-intensive and capital-intensive commodities. Besides, the analysis on trade competition and export similarity reveals that China and the Czech Republic may face fierce competition in capital-intensive products in the world market. China and the Czech Republic are proposed to optimize trade structure according to their comparative advantages and strengthen trade cooperation to achieve the reciprocal trade relations.
\end{abstract}

Keywords: China, the Czech Republic, trade, complementarity, competition.

\section{INTRODUCTION}

China established diplomatic relations with the former Czechoslovakia in 1949 and henceforward bilateral relation is good and the economic exchanges continued. China established diplomatic relations with the former Czechoslovakia in 1949. Henceforward, the two countries enjoy the good bilateral relations and economic exchanges. In 2016, Chinese president Xi Jinping had a state visit in the Czech Republic, which was the first time that head of state of China visited the Czech Republic since the establishment of diplomatic relations. This visit embodies that China has attached great importance to the cooperation with the Czech Republic as well as other countries in Eastern European and this visit is believed to promote the development of trade between China and Europe. Besides, the Czech Republic is also one of the countries along the Silk Road Economic Belt, and thus the relations between China and the Czech Republic will become much closer. China and the Czech Republic have maintained a positive and open attitude towards foreign trade in recent years. The proportion of trade volume has been rising and the bilateral trade has great significance for both countries. However, studies concerning the complementarity and competition between these two countries are limited. Therefore, this paper sheds light on and makes analysis of this issue. Besides, in order to promote the trade cooperation for reciprocity, proposals are advanced in line with the analysis of the complementarity and competition between China and the Czech Republic.

This paper presents the introduction and paper structure firstly and then followed with the literature review. Then, bilateral trade status of China and the Czech Republic is interpreted. In order to analyse complementarity and competition of China and the Czech Republic, empirical methods including TC, TCI and ESI are adopted to study the complementarity and competition of bilateral trade. Ultimately, this study draws conclusions and brings forth proposals for future trade cooperation.

\section{LITERATURE REVIEW}

Previous studies on trade between China and the Czech Republic are few, especially the complementarity and competition. Stehel and Šuleř (2016) acknowledge 
that China and the Czech Republic are both export oriented countries [1]. Castro et al. (2017) describe the relations between two countries in the aspects of trade and makes a thorough inquiry into the opportunities and challenges with the closer trade cooperation. Other scholars also focus on the complementarity between two countries [2]. Pavlínek et al. (2009) point out that the traditional data of trade may be misleading in the analysis of trade complementarity between China and the Czech Republic because the volume of trade balance and the value-added may not reflect the precise trade situation [3]. Gereffi and Fernandez (2010) consider that valueadded data linked to GVCs utilized to evaluate the trade between China and the Czech Republic is more accurate [4]. The value-added methods are also employed by other scholars like Éltető and Szunomár (2016) to analyse the trade structure of China and the Czech Republic. Besides, Scholars also point out the necessity of trade between both countries [5]. Shang (2012) states that trade between China and the Czech Republic is beneficial to expand foreign market and optimize trade structure [6]. According to OECD science (2007), the Czech Republic has cultivated qualitative comparative advantage in the industrial departments [7]. The Czech Republic, a country belongs to EU, is conduce to helping China have access to the EU market. Shang and Gao (2014) also notify that China has great trade competitiveness of its products and the market share enhances quickly, reshaping the market in the Czech Republic [8]. Castro et al. (2014) explains that because of the penetration of Czech exporters into the European market, it is easy to export commodities from the Czech Republic to other European countries [9]. Thus, it can facilitate the trade potential of China and help China strengthen competitiveness and expand the its market share in Europe. In addition, some scholars raise some suggestions for trade between both countries. Based on trade gravity model, it is recommended that the Czech Republic should export more commodities to China and both countries should increase the volume of bilateral trade (Gong and Chen, 2012) [10]. Rowland et al. (2019) suggest that the Czech Republic should look for the trade opportunities in China and pay attention to the development trends in the economy of China [11]. Besides, the Czech Republic is suggested to eliminate the threatening factors like market inflexibility and make progress in the science and technology, which is crucial for the development of trade between both countries (Fürst and Plechová, 2010) [12].

There is limited existing literature concerning trade between China and the Czech Republic and studies on the complementarity and competition is relatively lack. Therefore, this paper is intended for perfecting the blank area of research and provide reference for further studies by using theoretical models to comprehensively present the trade relations between China and the Czech Republic.

\section{ANALYSIS ON TRADE PATTERN BETWEEN CHINESE THE CZECH REPUBLIC}

The original data of trade volume from 2010-2020 used in this paper are from the United Nations Commodity Trade Statistics Database and the classification of merchandise trade is complied with the Standard Industrial Trade Classification Revision 3 (SITC Rev3). According to the characteristics of trade commodities, all commodities are divided into three categories. Resource-intensive commodities include SITC0 to SITC4, capital-intensive commodities include SITC5 and SITC7 and labour-intensive commodities are SITC6 and SITC8.

\subsection{Trade Status between China the Czech Republic}

Through the analysis of data, it reveals that from 2010 to 2020, China's export structure has improved to some extent. In terms of commodity types, three types of products with the largest export volume of China are SICT7, SICT8 and SITC6, which account for $97.6 \%$ of all the exports to the Czech Republic in 2020. Among them, SITC7 accounts for $82.2 \%$ of that year's exports, which continues to be the largest volume of commodities from 2010-2020 and the proportion gradually increases. In terms of commodity structure, the proportion of capital-intensive commodities has increased gradually from $81.2 \%$ to $83.5 \%$, which are undoubtedly the largest export categories from China to the Czech Republic. The share of resource-intensive products is relatively small and decreases year by year from $0.82 \%$ to $0.48 \%$, and the labour-intensive commodities also decreases for about $2.57 \%$.

In contrast, the Czech export structure has not improved evidently. In terms of commodity types, three types of products with the largest export volume are SICT7, SICT8 and SITC2, which account for $89.7 \%$ of the total export to China in 2020. SICT7 is the biggest type of export commodities as well, accounting for $66.7 \%$ but there is no significant change in the proportion from 2010 to 2020 so as the SITC2. SICT8 has increased for about $4.7 \%$. In terms of commodity structure, capitalintensive commodities are the major exports while the trade volume decreases from $71.8 \%$ to $69.4 \%$, which is not a promising sign for $\mathrm{Czech}$ export structure. The proportion of labour-intensive and resource-intensive commodities increases slightly around 1 percent.

Thus, capital-intensive commodities are the major exports of both countries. However, compared with the Czech Republic, China's export structure is of higher level, which is embodied in that capital-intensive intensive products have become its leading export products. 


\section{ANALYSIS AND DISCUSSION}

\subsection{Trade Complementarity Index}

TCI is used to calculate the degree of conformity between one country's exports and another country's imports, which reflects the complementarity of trade between the two countries as well as examines the potential of trade development. In the case of multiple products (or services), the comprehensive trade complementarity index of the two countries is the weighted average of the trade complementarity index of each product (or service). The Equation (1) and Equation (2) are:

$$
C_{\mathrm{ij}}=\mathrm{RCA}_{\mathrm{xi}}^{\mathrm{a}} \bullet \mathrm{RCA}_{\mathrm{mj}}^{\mathrm{a}}
$$

$\operatorname{RCA}_{\mathrm{xi}}^{\mathrm{a}}=\frac{X_{\mathrm{i}}^{\mathrm{a}} / \mathrm{X}_{\mathrm{i}}}{\mathrm{X}_{\mathrm{w}}^{\mathrm{a}} / \mathrm{X}_{\mathrm{w}}} \quad \operatorname{RCA}_{\mathrm{mj}}^{\mathrm{a}}=\frac{\mathrm{M}_{\mathrm{j}}^{\mathrm{a}} / \mathrm{M}_{\mathrm{j}}}{\mathrm{M}_{\mathrm{w}}^{\mathrm{a}} / \mathrm{M}_{\mathrm{w}}}$

$\mathrm{X}_{\mathrm{i}}^{\mathrm{a}} \& \mathrm{X}_{\mathrm{w}}^{\mathrm{a}}$ are total export of product a in country $\mathrm{i}$ and the whole world $w$ respectively.

$\mathrm{X}_{\mathrm{i}} \& \mathrm{X}_{\mathrm{w}}$ are total export of country a and all countries respectively.

$\mathrm{M}_{\mathrm{j}}^{\mathrm{a}} \& \mathrm{M}_{\mathrm{w}}^{\mathrm{a}}$ are total import of product an in country $\mathrm{j}$ and the whole world $w$ respectively.

$\mathrm{M}_{\mathrm{i}} \& \mathrm{M}_{\mathrm{w}}$ are total import of country $\mathrm{j}$ and all countries respectively.

The larger the index, the greater trade complementarity between country $i$ and its trading partners and the greater the potential of trade cooperation between the two countries.

Table 1 shows the complementarity of China's export and Czech Republic's imports. China's exports are most complement with Czech Republic's imports in the commodities of SITC6, SITC7 and SITC8. TCI of these categories are larger than 1 , which is considered as high complementarity. It indicates that China's exports have strong complementarity with Czech Republic's imports in labour-intensive and capital-intensive commodities. Even if China's exports to the Czech Republic are considerable in these products, the TCI indexes do not have significant improvement in these years, signifying that exports of capital-intensive from China to Czech have already been saturated. TCL indexes of SITC0, SITC1 and SITC2 have a decrescent trend, while indexes of SITC3 and SITC4 are getting bigger slightly. In all, for resource-intensive commodities, TCL indexes are relatively small, implying that the Czech Republic rarely import these resource-intensive products from China. Hence, China is recommended to export more resourceintensive commodities to improve the trade complementarity with the Czech Republic.

Table 2 illustrates the complementarity of Czech Republic's exports and China's imports. The trade complementarity of Czech Republic's exports to China in SITC2 and SITC7 are obviously strong. The TCI of SITC2 is always larger than 2, which shows that the Czech Republic exports a large quantity of crude materials, inedible, except fuels to China and meets the import demand of China. This is mainly because the Czech Republic has abundant resources and strong comparative advantages in SITC2. Concerning other resource-intensive goods, the complementarity is much smaller. SITC0 and SITC1 have a growing trend and the Czech Republic exports more food and animals as well as beverages and tobacco to China, which meets the increasing consumption needs of Chinese consumers. Given the TCI index of SITC7 is large, both countries have considerable complementarity in machinery and transport equipment.

Table 1. TCI of China and the Czech Republic from 2010 to 2020

\begin{tabular}{|c|c|c|c|c|c|c|c|c|c|c|}
\hline Year & SITC0 & SITC1 & SITC2 & SITC3 & SITC4 & SITC5 & SITC6 & SITC7 & SITC8 & SITC9 \\
\hline $\mathbf{2 0 1 0}$ & 0.379 & 0.119 & 0.113 & 0.070 & 0.015 & 0.512 & 1.659 & 1.756 & 1.933 & 0.012 \\
\hline $\mathbf{2 0 1 1}$ & 0.378 & 0.133 & 0.128 & 0.058 & 0.019 & 0.605 & 1.853 & 1.927 & 2.107 & 0.001 \\
\hline $\mathbf{2 0 1 2}$ & 0.411 & 0.150 & 0.119 & 0.052 & 0.018 & 0.608 & 1.993 & 1.818 & 2.042 & 0.001 \\
\hline $\mathbf{2 0 1 3}$ & 0.388 & 0.140 & 0.118 & 0.050 & 0.026 & 0.621 & 2.111 & 1.833 & 2.174 & 0.001 \\
\hline $\mathbf{2 0 1 4}$ & 0.330 & 0.125 & 0.122 & 0.050 & 0.028 & 0.609 & 1.967 & 1.762 & 2.075 & 0.001 \\
\hline $\mathbf{2 0 1 5}$ & 0.315 & 0.144 & 0.111 & 0.070 & 0.030 & 0.545 & 1.850 & 1.612 & 1.788 & 0.001 \\
\hline $\mathbf{2 0 1 6}$ & 0.334 & 0.165 & 0.106 & 0.072 & 0.031 & 0.566 & 1.888 & 1.545 & 1.963 & 0.002 \\
\hline $\mathbf{2 0 1 7}$ & 0.307 & 0.161 & 0.099 & 0.097 & 0.025 & 0.547 & 1.776 & 1.632 & 2.049 & 0.002 \\
\hline $\mathbf{2 0 1 8}$ & 0.300 & 0.158 & 0.108 & 0.098 & 0.028 & 0.571 & 1.779 & 1.737 & 1.979 & 0.002 \\
\hline $\mathbf{2 0 1 9}$ & 0.297 & 0.150 & 0.098 & 0.100 & 0.039 & 0.542 & 1.787 & 1.689 & 1.851 & 0.005 \\
\hline $\mathbf{2 0 2 0}$ & 0.289 & 0.114 & 0.095 & 0.184 & 0.110 & 0.427 & 1.580 & 1.567 & 1.491 & 0.016 \\
\hline
\end{tabular}


Table 2. TCI of China and the Czech Republic from 2010 to 2020

\begin{tabular}{|c|c|c|c|c|c|c|c|c|c|c|}
\hline Year & SITC0 & SITC1 & SITC2 & SITC3 & SITC4 & SITC5 & SITC6 & SITC7 & SITC8 & SITC9 \\
\hline $\mathbf{2 0 1 0}$ & 0.144 & 0.190 & 2.656 & 0.216 & 0.386 & 0.608 & 0.974 & 1.761 & 0.719 & 0.129 \\
\hline $\mathbf{2 0 1 1}$ & 0.161 & 0.230 & 2.495 & 0.202 & 0.328 & 0.581 & 0.912 & 1.904 & 0.696 & 0.016 \\
\hline $\mathbf{2 0 1 2}$ & 0.221 & 0.275 & 2.493 & 0.220 & 0.681 & 0.579 & 0.946 & 1.801 & 0.661 & 0.023 \\
\hline $\mathbf{2 0 1 3}$ & 0.231 & 0.277 & 2.521 & 0.164 & 0.630 & 0.601 & 0.942 & 1.853 & 0.674 & 0.035 \\
\hline $\mathbf{2 0 1 4}$ & 0.227 & 0.330 & 2.432 & 0.181 & 0.534 & 0.581 & 0.949 & 1.809 & 0.616 & 0.036 \\
\hline $\mathbf{2 0 1 5}$ & 0.271 & 0.432 & 2.305 & 0.308 & 0.576 & 0.524 & 0.794 & 1.704 & 0.606 & 0.041 \\
\hline $\mathbf{2 0 1 6}$ & 0.253 & 0.467 & 2.129 & 0.244 & 0.533 & 0.516 & 0.791 & 1.673 & 0.651 & 0.032 \\
\hline $\mathbf{2 0 1 7}$ & 0.226 & 0.470 & 2.232 & 0.279 & 0.337 & 0.513 & 0.724 & 1.670 & 0.644 & 0.025 \\
\hline $\mathbf{2 0 1 8}$ & 0.241 & 0.386 & 2.087 & 0.273 & 0.323 & 0.497 & 0.712 & 1.733 & 0.609 & 0.026 \\
\hline $\mathbf{2 0 1 9}$ & 0.296 & 0.403 & 2.190 & 0.287 & 0.466 & 0.512 & 0.680 & 1.633 & 0.562 & 0.028 \\
\hline $\mathbf{2 0 2 0}$ & 0.389 & 0.427 & 2.598 & 0.662 & 1.316 & 0.391 & 0.724 & 1.531 & 0.485 & 0.014 \\
\hline
\end{tabular}

TCI indexes of SICT6 and SITC8 are less than 1 and become smaller continuously, which indicates that Czech Republic's exports are less complementary with China's imports in labour-intensive commodities. To strengthen the trade complementarity, the Czech Republic is suggested to export more labour-intensive goods.

\subsection{Trade Competition Index}

The trade competitiveness index (TC) refers to the ratio of a country's net exports of a certain product (or service) to its total imports and exports of that product (or service). It takes both imports and exports into account in foreign trade. The Equation (3) is:

$\mathrm{TC}_{\mathrm{i}}^{\mathrm{a}}=\frac{\mathrm{X}_{\mathrm{i}}^{\mathrm{a}}-\mathrm{M}_{\mathrm{i}}^{\mathrm{a}}}{\mathrm{X}_{\mathrm{i}}^{\mathrm{a}}+\mathrm{M}_{\mathrm{i}}^{\mathrm{a}}}$

$\mathrm{TC}_{\mathrm{i}}^{\mathrm{a}}$ represents trade competitiveness index of country $\mathrm{i}$ in product a. $\mathrm{X}_{\mathrm{i}}^{\mathrm{a}}$ and $\mathrm{M}_{\mathrm{i}}^{\mathrm{a}}$ are the export volume and import volume of a products in i country respectively, and the index value is in the range of $(-1,+1)$.

The TC of China and the Czech Republic is presented in table 3. The overall competitiveness of both countries in commodity trade is not so strong, but China's TC are greater than 0 in the sample range, showing certain competitive advantages. Both countries' TC indexes show a general ascending trend.

The TC indexes of China and the Czech Republic in commodities are displayed in table 4 and table 5. The top three competitive commodity categories in China are SITC8, SITC6 and SITC7, which means China mainly has advantages in labor-intensive and capital-intensive goods, while China does not have comparative advantages in resource-intensive products. This is because China has abundant labor force and its strength in capital has been significantly improved in recent years.
However, China is also a resource-consuming country and many energy-related products need to be imported from other countries, and thus China is uncompetitive in resource-intensive goods. The Czech Republic has competitiveness in SITC7 and SITC4, which implies its capital-intensive and resource-intensive products are competitive. The Czech Republic is rich in coal and it is a developed country with sufficient capital. The consequences are also complied with its resource endowment. The variances in TC of these two countries reflect that there are some differences in the international competitiveness of each country's products. In addition, the competitiveness index of China's capital-intensive and labor-intensive products has become larger in recent years and hence it can be concluded that the competitiveness has been improved. However, there is no significant change of these two categories in the Czech Republic, while its competitiveness in resource-intensive products has improved, which is contrary to China.

Table 3. TC of China and the Czech Republic from 2010 to 2020

\begin{tabular}{|c|c|c|}
\hline Year & China & the Czech \\
\hline $\mathbf{2 0 1 0}$ & 0.0611 & 0.0250 \\
\hline $\mathbf{2 0 1 1}$ & 0.0426 & 0.0370 \\
\hline $\mathbf{2 0 1 2}$ & 0.0596 & 0.0564 \\
\hline $\mathbf{2 0 1 3}$ & 0.0623 & 0.0625 \\
\hline $\mathbf{2 0 1 4}$ & 0.0891 & 0.0643 \\
\hline $\mathbf{2 0 1 5}$ & 0.1502 & 0.0553 \\
\hline $\mathbf{2 0 1 6}$ & 0.1383 & 0.0649 \\
\hline $\mathbf{2 0 1 7}$ & 0.1022 & 0.0560 \\
\hline $\mathbf{2 0 1 8}$ & 0.0776 & 0.0454 \\
\hline $\mathbf{2 0 1 9}$ & 0.0941 & 0.0533 \\
\hline $\mathbf{2 0 2 0}$ & 0.1152 & 0.0596 \\
\hline
\end{tabular}


Table 4. TC of China from 2010 to 2020 in commodities

\begin{tabular}{|c|c|c|c|c|c|c|c|c|c|c|}
\hline Year & SITC0 & SITC1 & SITC2 & SITC3 & SITC4 & SITC5 & SITC6 & SITC7 & SITC8 & SITC9 \\
\hline $\mathbf{2 0 1 0}$ & 0.312 & -0.120 & -0.896 & -0.753 & -0.917 & -0.261 & 0.310 & 0.174 & 0.538 & -0.852 \\
\hline $\mathbf{2 0 1 1}$ & 0.274 & -0.236 & -0.900 & -0.790 & -0.906 & -0.223 & 0.360 & 0.177 & 0.565 & -0.910 \\
\hline $\mathbf{2 0 1 2}$ & 0.193 & -0.259 & -0.899 & -0.820 & -0.916 & -0.223 & 0.391 & 0.193 & 0.595 & -0.960 \\
\hline $\mathbf{2 0 1 3}$ & 0.144 & -0.267 & -0.903 & -0.806 & -0.892 & -0.227 & 0.418 & 0.188 & 0.616 & -0.968 \\
\hline $\mathbf{2 0 1 4}$ & 0.114 & -0.289 & -0.889 & -0.804 & -0.864 & -0.177 & 0.398 & 0.193 & 0.635 & -0.947 \\
\hline $\mathbf{2 0 1 5}$ & 0.070 & -0.271 & -0.876 & -0.754 & -0.841 & -0.137 & 0.490 & 0.216 & 0.630 & -0.946 \\
\hline $\mathbf{2 0 1 6}$ & 0.108 & -0.265 & -0.878 & -0.736 & -0.846 & -0.146 & 0.482 & 0.199 & 0.618 & -0.860 \\
\hline $\mathbf{2 0 1 7}$ & 0.078 & -0.339 & -0.894 & -0.752 & -0.823 & -0.153 & 0.456 & 0.191 & 0.611 & -0.840 \\
\hline $\mathbf{2 0 1 8}$ & 0.010 & -0.347 & -0.880 & -0.764 & -0.780 & -0.140 & 0.452 & 0.180 & 0.601 & -0.851 \\
\hline $\mathbf{2 0 1 9}$ & -0.102 & -0.375 & -0.890 & -0.759 & -0.795 & -0.147 & 0.485 & 0.208 & 0.608 & -0.618 \\
\hline $\mathbf{2 0 2 0}$ & -0.208 & -0.430 & -0.903 & -0.786 & -0.785 & -0.112 & 0.440 & 0.206 & 0.603 & 0.122 \\
\hline
\end{tabular}

Table 5. TC of the Czech Republic from 2010 to 2020 in commodities

\begin{tabular}{|c|c|c|c|c|c|c|c|c|c|c|}
\hline Year & SITC0 & SITC1 & SITC2 & SITC3 & SITC4 & SITC5 & SITC6 & SITC7 & SITC8 & SITC9 \\
\hline $\mathbf{2 0 1 0}$ & -0.193 & 0.077 & 0.088 & -0.422 & 0.015 & -0.214 & 0.018 & 0.140 & 0.070 & -0.111 \\
\hline $\mathbf{2 0 1 1}$ & -0.149 & 0.025 & 0.008 & -0.423 & -0.086 & -0.247 & 0.017 & 0.166 & 0.081 & -0.077 \\
\hline $\mathbf{2 0 1 2}$ & -0.117 & 0.034 & 0.049 & -0.415 & 0.260 & -0.249 & 0.037 & 0.185 & 0.117 & -0.121 \\
\hline $\mathbf{2 0 1 3}$ & -0.113 & 0.066 & 0.043 & -0.477 & 0.154 & -0.241 & 0.042 & 0.193 & 0.131 & -0.054 \\
\hline $\mathbf{2 0 1 4}$ & -0.098 & 0.162 & 0.054 & -0.455 & 0.140 & -0.224 & 0.031 & 0.182 & 0.117 & 0.019 \\
\hline $\mathbf{2 0 1 5}$ & -0.100 & 0.173 & 0.065 & -0.323 & 0.149 & -0.248 & 0.017 & 0.151 & 0.104 & 0.094 \\
\hline $\mathbf{2 0 1 6}$ & -0.103 & 0.172 & 0.054 & -0.383 & 0.109 & -0.262 & 0.017 & 0.166 & 0.096 & 0.094 \\
\hline $\mathbf{2 0 1 7}$ & -0.122 & 0.137 & 0.071 & -0.458 & 0.097 & -0.229 & -0.003 & 0.158 & 0.086 & 0.085 \\
\hline $\mathbf{2 0 1 8}$ & -0.132 & 0.054 & 0.073 & -0.482 & 0.149 & -0.238 & -0.002 & 0.148 & 0.072 & 0.117 \\
\hline $\mathbf{2 0 1 9}$ & -0.145 & 0.061 & 0.089 & -0.471 & 0.118 & -0.215 & 0.006 & 0.152 & 0.069 & 0.082 \\
\hline $\mathbf{2 0 2 0}$ & -0.119 & 0.146 & 0.111 & -0.443 & 0.124 & -0.210 & 0.026 & 0.141 & 0.080 & 0.019 \\
\hline
\end{tabular}

\subsection{Export Similarity Index}

The ESI examines the export similarity of both countries in the world market from the perspective of export product structure, so as to further reflect the competitiveness and complementarity of the two countries in the world market. The Equation (4) is:

$S^{\mathrm{p}}(i j, n)=\sum_{\mathrm{a}}\left[\frac{\mathrm{X}_{\mathrm{in}}^{\mathrm{a}} / \mathrm{X}_{\mathrm{in}}+\mathrm{X}_{\mathrm{jn}}^{\mathrm{a}} / \mathrm{X}_{\mathrm{jn}}}{2}\right]\left[1-\mid \frac{\mathrm{X}_{\mathrm{in}}^{\mathrm{a}} / \mathrm{X}_{\mathrm{in}}-\mathrm{X}_{\mathrm{jn}}^{\mathrm{a}} / \mathrm{X}_{\mathrm{jn}}}{\mathrm{X}_{\mathrm{in}}^{\mathrm{a}} / \mathrm{X}_{\mathrm{in}}+\mathrm{X}_{\mathrm{jn}}^{\mathrm{a}} / \mathrm{X}_{\mathrm{jn}}}\right] \times 100$

$\mathrm{S}^{\mathrm{p}}(\mathrm{ij}, \mathrm{n})$ refers to the similarity index of products (or services) exported by countries $i$ and $j$ to the world market. $X_{\text {in }}^{a} / X_{\text {in }} \& X_{j n}^{a} / X_{j n}$ respectively represent the share of a products (or services) exported by country $\mathrm{i}$ and country $\mathrm{j}$ to the world market in their total exports. The index range is $[0,100]$. The larger the value is, the more similar the export structure of the two countries in the world market is, and hence the fiercer the competition is.

Table 6. demonstrates the export similarity of China and the Czech Republic. Overall, the change of export similarity between the two countries is not significant and the ESI fluctuates slightly from 2010 to 2020. Concerning the commodity types, SITC7 is the product with the highest ESI of both countries. The equipment of machine and transport of China and the Czech Republic has always been the leading export product. Both countries have advanced technology in this industry and have implemented much capital to support the production. Meanwhile, the capital-intensive goods of SITC5 and SITC7 have steady improvements, which shows both countries are devoted to transform into better economic structure. Then, SITC6 and SITC8 are also the commodities with high ESI. These two categories belong to the labour-intensive commodities and hence the labour-intensive products of both countries may face 
Table 6. ESI of China and the Czech Republic from 2010 to 2020

\begin{tabular}{|c|c|c|c|c|c|c|c|c|c|c|}
\hline Year & SITC0 & SITC1 & SITC2 & SITC3 & SITC4 & SITC5 & SITC6 & SITC7 & SITC8 & SITC9 \\
\hline $\mathbf{2 0 1 0}$ & 2.608 & 0.121 & 0.735 & 1.691 & 0.025 & 5.547 & 15.789 & 49.505 & 10.694 & 0.093 \\
\hline $\mathbf{2 0 1 1}$ & 2.660 & 0.120 & 0.789 & 1.700 & 0.030 & 6.043 & 16.833 & 47.546 & 10.546 & 0.123 \\
\hline $\mathbf{2 0 1 2}$ & 2.542 & 0.126 & 0.700 & 1.514 & 0.029 & 5.541 & 16.310 & 47.115 & 10.969 & 0.069 \\
\hline $\mathbf{2 0 1 3}$ & 2.523 & 0.118 & 0.659 & 1.529 & 0.028 & 5.413 & 16.378 & 47.059 & 11.687 & 0.078 \\
\hline $\mathbf{2 0 1 4}$ & 2.515 & 0.123 & 0.676 & 1.471 & 0.029 & 5.741 & 16.554 & 45.759 & 11.716 & 0.097 \\
\hline $\mathbf{2 0 1 5}$ & 2.558 & 0.146 & 0.612 & 1.227 & 0.030 & 5.697 & 15.823 & 46.659 & 12.207 & 0.105 \\
\hline $\mathbf{2 0 1 6}$ & 2.912 & 0.169 & 0.625 & 1.281 & 0.029 & 5.809 & 15.427 & 46.984 & 13.211 & 0.248 \\
\hline $\mathbf{2 0 1 7}$ & 2.809 & 0.153 & 0.639 & 1.564 & 0.039 & 6.092 & 14.949 & 47.962 & 12.935 & 0.254 \\
\hline $\mathbf{2 0 1 8}$ & 2.657 & 0.149 & 0.691 & 1.869 & 0.045 & 6.146 & 14.934 & 48.596 & 12.223 & 0.245 \\
\hline $\mathbf{2 0 1 9}$ & 2.638 & 0.140 & 0.657 & 1.724 & 0.048 & 6.481 & 14.164 & 48.029 & 12.048 & 0.376 \\
\hline $\mathbf{2 0 2 0}$ & 2.489 & 0.096 & 0.578 & 1.198 & 0.056 & 6.530 & 13.861 & 48.700 & 12.288 & 0.391 \\
\hline
\end{tabular}

intense competition in the world market. It is estimated that with the up-market structure of China's export commodities, the intensity of competition will ease slightly in the future. The export similarity of resourceintensive products between the two countries is very low and probably there will be little competition. The ESI of SITC0, SITC1 and SITC2 have small decrease, while resource-intensive products of SITC3 and SITC4 have an increasing trend. Through the analysis above, it can be found that both two countries have similar development trends to shift to high value-added sectors. Therefore, the trade competition in capital-intensive products between China and the Czech Republic in the world market will be intense.

\section{CONCLUSION}

With the continued implementation of the initiative of "The Belt and Road", there is a general trend that the scale of trade between China and the Czech Republic will expand. However, studies on this area is relatively lack. Therefore, this paper is intended for perfecting the blank area of research and highlighting studies on trade relations between China and the Czech Republic. In this paper, modern indicators like TC, TCI and ES are utilized to analyse trade complementarity and competition between China and the Czech Republic and some proposals are made advance the bilateral trade on the basis of the analysis. The results can be summed up in the following aspects.

Firstly, from the perspective of trade structure, China and the Czech Republic has made improvements in the trade structure to a certain extent in recent years and the trade volume keeps increasing. Capital-intensive goods are the main commodities that China imports from and exports to the Czech Republic. China also exports a large quantity labour-intensive goods to the Czech Republic, while resource-intensive goods account for a relatively large proportion of Czech Republic's exports.

Secondly, the empirical results show that China's exports of labour-intensive products are most complementary with Czech Republic's import, while the Czech Republic's exports of resource-intensive products of SITC2 have the highest complementarity with China's import. Both countries can continue to leverage their comparative advantages and increase exports of such commodities to meet each other's consumption needs. Meanwhile, it is recommended that China can export more resource-intensive commodities and the Czech Republic is suggested to export more labour-intensive goods to strengthen the trade complementarity,

Thirdly, in terms of competitiveness, China is competitive in labour-intensive and capital-intensive goods, while the Czech Republic has comparative advantages in resource-intensive and capital-intensive products. Combined with the analysis of export similarity, capital-intensive goods, especially SITC7 are the leading export products of both countries in world market. It can be seen that both countries will focus on the high value-added industries and improve their trade structure. Therefore, two countries may face fiercer competition in the international market of capitalintensive products. China and the Czech Republic should differentiate their capital-intensive products to avoid direct competition in the international market, and actively export the value-added products to improve their competitiveness in trade. 


\section{REFERENCES}

[1] V. Stehel, P. Šuleř, Foreign trade between China and the Czech Republic, Littera Scripta, vol. 9, no. 3, 2016, pp. 84-95.

[2] T. Castro, J. Vlčková, P. Hnát, Trade and investment relations between the Czech Republic and China: the Czech Republic as a gateway to the EU?, Society and Economy, vol. 39, no. 4, 2017, pp. 481-499.

[3] P. Pavlínek, B. Domański, R. Guzik, Industrial upgrading through foreign direct investment in central European automotive manufacturing, European Urban and Regional Studies, vol. 16, no. 1, 2009, pp. 43-63.

[4] G. Gereffi, K. Fernandez-Stark, The Offshore Services Value Chain: Developing Countries and the Crisis. World Bank: World Bank Press, 2010.

[5] A. Éltető, Á. Szunomár, Chinese investment and trade: strengthening ties with central and eastern Europe", International Journal of Business and Management, vol. 4, no. 1, 2016, pp. 24-48.

[6] Y. Shang, A characteristic analysis of good trade structure between China and middle east European countries", Theoretical Exploration, vol. 6, 2012, pp. 77-79.

[7] Organisation for Economic Co-operation and Development Science (OECD Science), Technology and Industry Scoreboard 2007: Innovation and performance in the global economy, Paris: OECD Publications, 2007.

[8] Y. Shang, Y. Gao, A research on export product competitiveness and structure effect between China and 10 central and eastern European countries from 2002 to 2011: an empirical study based on CMSA model, World Economy Study, vol. 4, 2014 pp.3238 .
[9] T. Castro, Z. Stuchlíková, China-V4 trade relations - a Czech perspectives, in: Mráz, S. \& Brocková, K. (eds) Current Trends and Perspectives in Development of China-V4 Trade and Investment, Bratislava: Vydavatel'stvo EKONÓM, 2014.

[10] J. Gong, X. Chen, An empirical study of the trade between China and middle east European based on gravity model, Prices Monthly, vol. 11, 2010, pp. 63-66.

[11] Z. Rowland, P. Šuleř, M. Vochozka, Comparison of neural networks and regression time series in estimating the Czech Republic and China trade balance, SHS Web of Conferences 61, 01023 (2019).

[12] R. Fürst, G. Pleschová, Czech and Slovak Relations with China: contenders for China's favour, EuropeAsia Studies, vol. 62, no. 8, 2010, pp. 1363-1381. 